\title{
PENGARUH KEGIATAN FINGER PAINTING TERHADAP KREATIVITAS ANAK KELOMPOK B
}

\author{
Sri rahayu Hader1', Bahran Taib ${ }^{2}$, Santi M.J.Wahid ${ }^{3}$ \\ Universitas Khairun Ternate \\ Fakultas Keguruan dan Ilmu Pendidikan \\ Jl.Bandarah Sultan Babullah Kota Ternate Utara,Kotak Pos 53 Teranate 977328 \\ Telpon:(0921)3110905-Faksimili 0921-3110901 \\ Email: Rahayu06hader@gmail.com², taibbahra4685@gmail.com². \\ santi.wahid@gmail.com³. Umikalsumarfa@yahoo co.id ${ }^{4}$
}

\begin{abstract}
Abstrak: Kreativitas sangat penting untuk dikembangkan bagi anak usia dini karena akan menciptakan pengalaman-pengalaman yang bisa menumbuhkan percaya diri dan sikap positif untuk perkembangan anak secara optimal. Adapun salah satu finger painting yang dapat mengembangkan kemampuan kreativitas anak yaitu melalui kegiatan finger painting, dengan kegiatan finger painting merupakan salah satu kegiatan untuk mengembangkan kreativitas anak. Metode penelitian yang digunakan dalam penelitian ini dengan pendekatan studi (library research). Adapun salah satu kegiatan yang dapat diterapkan dalam mengembangkan kreativitas anak yaitu dengan menggunakan finger painting. Dapat disimpulkan bahwa ada pengaruh teknik melukis (finger painting) terhadap kreativitas anak.
\end{abstract}

Kata Kunci: Kegiatan Finger Painting, Kreativitas Anak

\begin{abstract}
Creativity is very important thing to be develop for early childhood because it will creates experiences that can foster self-confidence and positive attitude for optimal child development. One of the finger painting that can develop children's creativity is by doing finger painting activities, with finger painting activities is one of the activities for develop children's creativity. The research method used is library research. One of the activities can be applied for developing children's creativity is finger painting. It can be concluded that there is influence of finger painting on children's creativity.
\end{abstract}

keywords: Finger Painting Activities, Children's Creativity

\section{A. Pendahuluan}

Pendidikan anak usia dini merupakan pendidikan prasekolah sebelum menempuh pendidikan sekolah dasar. Berdasarkan undang-undang Sistem Pendidikan Nasional Nomor 20 Tahun 2003 pasal 28 ayat 1 yang tergolong dalam pendidikan anak usia dini adalah usia 0-6 tahun. Selanjutnya, peraturan Mentri Pendidikan dan Kebudayaan Nomor 84 Tahun 2014 tentang Standar Pendidikan Anak Usia Dini pada pasal 1 ayat 3, terdapat satuan pendidikan anak usia dini yakni taman kanak-kanak (TK), Taman Kanak-Kanak Luar Biasa (TKLB), Kelompok Bermain (KB), Taman Penitipan Anak (TPA) dan Satuan Paud Sejenis (SPS). TK dan TKLB merupakan pendidikan jalur formal yang diselenggarakan untuk anak usia 4-6 tahun, namun diperioritaskan untuk anak usia 5-6 tahun. Kemudian satuan pendidikan yang termasuk pada jalur nonformal.

Kreativitas merupakan hal yang sangat penting bagi individu dalam menjalani kehidupan. Dengan memiliki kreativitas seseorang akan dapat menyelesaikan masalahnya dengan mudah, karena dengan kreativitas seseorang tersebut akan menemukan jalan keluar dari permasalahannya dan biasanya jalan keluar tersebut merupakan jalan yang unik berbeda dengan orang lain. Dalam hal ini, kreativitas 
merupakan kemampuan untuk memberikan gagasan-gagasan baru dan menerapkannya dalam pemecahan masalah.

Perkembangan anak usia dini menjadi empat ranah utama, yaitu: perkembangan fisik, intelektual yang termasuk kognitif dan Bahasa, serta emosi dan sosial, yang di dalamnya juga termasuk perkembangan moral. Kreativitas anak usia dini dapat dilihat ketika dalam proses pembelajaran apakah anak tersebut memiliki rasa ingin tahu atau tidak, anak mampu mengerjakan tugas yang diberikan guru dengan baik atau tidak, anak memiliki imajinasinya sendiri atau tidak dan lain-lain.

Kreativitas yang dimiliki oleh anak usia dini banyak yang tidak diketahui oleh guru. Biasanya, anak yang selalu bertanya akan dimarahi oleh guru karena guru merasa bahwa anak tersebut cerewet dan tidak bisa diam. Padahal anak yang memiliki rasa ingin tahu tinggi adalah termasuk anak yang memiliki kreativitas. Jika sejak usia dini rasa ingin tahu anak sudah dipatahkan, dengan kata lain guru tersebut telah menghambat perkembangan kreativitas anak tersebut.

Anak yang dilarang untuk melakukan eksplorasi dengan alasan takut, maka hal tersebut juga menghambat perkembangan kreativitas anak. Misalnya, anak dilarang bermain pasir, dilarang bermain cat, dilarang bermain air, dan hal-hal yang membuat anak menjadi kotor. Pada intinya orang tua ataupun guru melarang hal tersebut karena mereka tidak mau capek. Misalnya jika baju anak kotor karena cat, orang tua malas mencuci pakaian anak yang kotor karena susah untuk dibersihkan. Sehingga banyak kita jumpai anak yang takut untuk kotor karena takut dimarahi oleh orang tuanya.

Setelah diidentifikasi, penyebab belum berkembangnya kreativitas anak ialah kurang aktifnya guru dalam proses pembelajaran sehingga kurang menarik rasa ingin tahu anak, kurangnya media yang menarik, kurangnya kegiatan yang mampu mengembangkan kreativitas anak. Oleh karena itu, diperluakan suatu kegiatan yang dapat mengembangkan kreativitas anak, salah satunya adalah kegiatan finger painting.

Finger Painting adalah jenis kegiatan membuat gambar/melukis yang dilakukan dengan cara mengoleskan adonan warna secara langsung dengan jari tangan secara bebas di atas bidang gambar, batasan jari di sini adalah semua jari tangan, telapak tangan, sampai pergelangan tangan. Finger Painting dapat mengembangkan ekspresi dalam media lukis dengan gerakan tangan, mengembangkan fantasi, imajinasi dan kreasi, melatih otot-otot tangan/ jari, koordinasi mata dan tangan, melati kecakapan mengombinasikan warna, memupuk perasaan terhadap gerakan tangan dan memupuk keindahan.

Finger Painting (melukis mengunakan cat basah/cair) merupakan pengalaman yang menarik dan mengesankan bagi setiap anak. Anak akan merasakan sensasi pada saat menyentu cat dan melakukan serangkaian gerak eksploratif yang bervariasi di atas kertas. Dengan bebas dan spontan anak dapat membuat gambar atau sapuansapuan warna yang lebih ekspresif.

Dari penjelasan di atas, tampaklah bahwa kegiatan finger painting menarik dilakukan untuk mengembangkan kreativitas anak. Dengan finger painting, anak diharapkan mampu mengombinasikan warna sehingga terciptalah suatu karya yang indah dari seorang anak serta anak tidak takut untuk mengotori tangannya dengan berani untuk mencelupkan tangan atau jari-jarinya ke dalam cat pewarna yang basah/cair. Dengan demikian penelitian ini bertujuan untuk melatih motorik halus anak, sehingga dapat menambah keterampilan anak.

\section{B. Metode Penelitian}

Metode penelitian yang digunakan dalam penelitian ini dengan pendekatan studi (library research). Menurut Zeed Mestika (2004) menyatakan bahwa metode penelitian dengan pendekatan study literatur merupakan penelitian yang serangkaian 
kegiatannya dengan metode pengumpulan data pustaka, buku-buku, serta tulisan yang terkait dengan judul penelitian ini dari perpustakaan kamus online dan internet yang dapat memperkuat naskah yang akan dipublikasikan.

\section{Pembahasan}

\section{Kreativitas}

a. Pengertian Kreativitas

Kreativitas berasal dari kata kreatif. Dalam Kamus Besar Bahasa Indonesia, kreatif berarti memiliki daya cipta, memiliki kemampuan untuk menciptakan. Jadi kreativitas adalah suatu kondisi, sikap, atau keadaan yang sangat khusus sifatnya dan hampir tidak mungkin dirumuskan secara tuntas. Kreativitas dapat didefinisikan dalam istilah kreativitas dalam kehidupan sehari-hari selalu dikaitkan dengan prestasi yang istimewa dalam menciptakan sesuatu yang baru, menemukan cara-cara pemecahan masalah yang tidak dapat ditemukan oleh kebanyakan orang, dan melihat adanya berbagai kemungkinan (Rohani, 2017: 11)

Kreatif merupakan satu sifat yang dimiliki oleh seseorang yang mempunyai kreativitas. Hal ini dikarenakan hanya orang kreatif yang mempunyai ide gagasan kreatif dan original. Orang akan menjadi kreatif apabila mampu menghasilkan produk secara kreatif serta tidak tergantung dengan orang lain yang berarti bahwa dalam memuaskan diri bukan karena tekanan dari luar. Amabile dalam (Suratno, 1999: 12) menjelaskan bahwa motivasi dalam diri atau intrinsik dengan sendirinya dan mendorong timbulnya kreativitas, dan itu akan berlangsung dalam kondisi mental tertentu.

Menurut (Santrock, 2011: 11) kreativitas merupkan kemampuan untuk memikirkan sesuatu dengan cara yang baru dan tidak biasa serta melahirkan solusi yang unik terhadap masalah-masalah yang dihadapi timbulnya kreativitas dan itu akan berlangsung dalam kondisi mental tertentu. Kreativitas penting dipupuk dan dikembangkan dalam diri anak karena dengan berkreasi orang dapat mewujudkan dirinya, dan perwujudan diri termasuk salah satu kebutuhan pokok dalam hidup manusia. Kreativitas atau berpikir, sebagai kemampuan untuk melihat bermacam-macam kemungkinan penyelesaian terhadap suatu masalah, merupakan bentuk pemikiran yang sampai saat ini masih kurang mendapat perhatian dalam pendidikan formal.

Kreativitas merupakan fenomena, dimana seseorang (person) mengkomunikasikan sebuah konsep baru (product) yang diperoleh sebagai hasil dari proses mental (process) dalam menghasilkan ide, yang merupakan upaya untuk memenuhi adanya kebutuhan (press) yang dipengaruhi tekanan ekologis (Kim, M Roh \& Cho, 2016: 19).

Stenberg, Kaufman dan Pretz (2002) menyatakan kreativitas sebagai kemampuan untuk menghasilkan produk yang baru, pantas dengan kualitas tinggi, yang akhirnya digunakan kebanyakan peneliti definisi umum kreativitas. Kreativitas juga dapat dilihat dari bagaimana individu mementingkan sebuah proses dalam melakukan pemecahan masalah dan peneliti terbaru menyatakan bahwa kreativitas harus dikembangkan dalam pemecahan masalah dalam konteks di dunia nyata.

Guiford dalam Mohammad Ali dan Mohammad Asroni (2004: 332) menyatakan bahwa kreativitas mengacu pada kemampuan yang menandai ciriciri orang kreatif, ada dua cara berpikir, yakni cara berpikir konvergen dan divergen. Cara berpikir konvergen adalah cara-cara individu dalam memikirkan sesuatu yang berpandagan bahwa hanya ada satu jawaban yang benar, sedangkan cara berpikir divergen adalah kemampuan individu untuk mencari berbagai alternatif jawaban terhadap suatu persoalan. Dalam 
kaitannya dengan kreativitas, bahwa menekankan orang-orang kreatif lebih banyak memiliki cara-cara berpikir divergen daripada konvergen.

Kreativitas adalah kemampuan yang mencerminkan kelancaran, keluwesan, dan orisinalitas dalam berpikir, serta kemampuan untuk mengolaborasi suatu gagasan. Lebih lanjut dijelaskan bahwa kreativitas sebagai keseluruhan kepribadian yang merupakan hasil interaksi dengan lingkungannya. Artinya, lingkungan yang merupakan tempat individu berinteraksi itu dapat mendukung berkembangnya kreativitas, tetapi ada juga justru menghambat berkembangnya kreativitas individu (Kenedi, 2017: 4).

Kreativitas anak usia dini adalah kemampuan anak dalam memiliki energi fisik dan mental yang sehat,cerdas, bersemangat,punya keingintahuan percaya diri,terbuka dan penuh daya cipta. Kemampuan dalam memiliki dorongan yang tinggi,memiliki keterlibatkan yang tinggi,memiliki rasa ingin tahu dan kebebasan dalam berekspresi

b. Ciri-Ciri Kreativitas

Setelah memahami pengertian kreaktivitas, maka kita akan memahami tentang ciri-ciri kreaktivitas itu sendiri. Amin (2007: 144), ciri-ciri kreaktivitas dapat dikelompokkan dalam dua kategori yaitu kognitif dan non kognitif. Ciri kognitif yaitu diantaranya orisinalitas, fleksibilitas, kelancaran dan elaborasi. Sedangkan nonkognitif diantaranya motivasi sikap dan kepribadian kreatif. Kedua ciri ini sama pentingnya, kecerdasan yang tidak ditunjang dengan kepribadian kreatif tidak anak menghasilkan apapun. Kreaktivitas hanya akan dihasilkan oleh orang yang cerdas yang memiliki kondisi psikologi yang sehat. Kreaktivitas tidak hanya perbuatan otak saja namun variabel emosi dan kesehatan mental sangat sehat sangat sulit mengahsilkan karya kreatif.

Adapun ciri-ciri perilaku yang mencerminkan kreativitas alamiah anak khususnya pada anak usia prasekolah, seperti:

1) Senang menjajaki lingkungannya

2) Mengamati dan memegang segala sesuatu,mendekati segala macam tempat atau pojok, seakan-akan haus akan pengalaman.

3) Rasa ingin tahu mereka besar, karena itu mereka suka mangajukan pertanyaan, dan seakan-akan tidak pernah puas dengan jawaban yang di berikan.

4) Anak usia prasekolah bersifat spontan dan cenderung menyatakan pikiran dan perasaannya sebagai mana adanya, tanpa merasakan hambatan,seperti tampak pada orang dewasa.

5) Anak usia prasekolah selalu ingin pendapatkan pengalaman-pengalaman baru, ia senang "berpetualang", dan terbuka terhadap rangsanganrangsangan baru yang mana sering mencemaskan orang tuanya.

6) mereka senang melakukan "eksperimen" hal ini tampak dari perilakunya senang mencoba-coba dan melakukan hal-hal yang sering membuat orang tuanya atau gurunya keheran-heranan dan tidak jarang pula merasa tidak berdaya menghadapi tingkah laku anaknya.

7) Anak usia prasekolah jarang merasa bosan,ia senang melakukan macammacam hal, dan ada-ada saja yang ingin di lakukan.

8) Biasanya anak usia prasekolah mempunyai daya imajinasi tinggi, yang nyata jika orang dewasa menyempatkan untuk mendegar ungkapanungkapan dan mengamati perilakunya.

Ciri-ciri kreativitas anak dapat diketahui melalui pengamatan terhadap perilaku anak yang berbeda dengan anak pada umumnya. Perbedaan perilaku anak tersebut biasanya membuat orang tua cemas dan bagi orang tua yang 
belum memahami tentang ciri-ciri anak kreatif biasanya menganggap sebagai anak nakal

Bakat dalam bentuk kreativitas akan tumbuh dan berkembang jika di dukung dengan fasilitas dan kesempatan yang memungkinkan. Orang tua danguru harus Kreativitas ditinjau dari segi proses yaitu sebagai suatu kemampuan untukmembentuk kombinasi-kombinasi baru dari dua konsep atau lebih yang sudah pikiran. Segi produk, kreativitas adalah kemampuan untuk menciptakan ataumenghasilkan produk-produk baru atau kombinasi dari hal sebelumnya yangsudah ada. Produk tersebut dapat berupa ide-ide baru, penemuan-penemuan baru,maupun teknologi baru yang memungkinkan manusia dapat meningkatkankualitas hidupnya.

Ciri-ciri Kreativitas Anak menurut Utami Munandar (2009:15) meliputi:

1) Rasa ingin tahu yang luas dan mendalam

2) Sering mengajukan pertanyaan yang baik,

3) Memberikan banyak gagasan atau usul terhadap suatu masalah

4) Bebas dalam menyatakan pendapat

5) Mempunyai rasa keindahan yang dalam

6) Menonjol dalam salah satu bidang seni

7) Mampu melihat suatu masalah dari berbagai segi/sudut pandang

8) Mempunyai rasa humor yang luas

9) Mempunyai daya imajinasi

10) Orisinal dalam ungkapan gagasan dan dalam pemecahan masalah.

Berdasarkan karakteristik kreativitas anak dalam penelitian ini adalah kreativitas yangmenunjukkan kelancaran anak dalam mengolah melalui media lukis dengan menggunakan bagian telapak tangan, melati kecakapan mengkombinasikan warna jari. melukis adonan menjadi barang yang unik dan menarik. Kreativitas anak yang menunjukkan keluwesan anak dalam menceritakan hasil olahan bentuk produk.Kreativitasanak yang menunjukkan keaslian murni dari anak tersebut, dan kreativitas anak yang dilihatdari elaborasi atau penjelasan anak mengenai pengembangan ide anak dari hasilbahan yang sudah disediakan yang telah dibuatnya.Kreativitas adalah kemampuan untuk memberikan gagasan-gagasan baru dan menerapkannya dalam pemecahan masalah.Perkembangan kreativitas anak sangat penting dari sejak dini untuk menunjang keberhasilan hidupnya.

c. Kreativitas Anak Usia Dini

Menurut Sari (2016: 34), pada dasarnya manusia dimanapun berada telah memiliki potensi kreatif. Namun, seiring perkembangan zaman, kreativitas tersebut lama-kelamaan hilang. Sebagai contoh, anak yang pada awal kehidupan antusias mencari tahu, gemar bertanya, gemar berkarya, namun setelah masuk sekolah anak dituntut untuk menjadi anak manis, penurut, dan tidak berbicara. Hal ini tentunya, akan membatasi kebebasan anak untuk berkreasi dan mengekspresikan diri. Hingga ke tingkat mahasiswa, sebagian besar sudah tidak mampu untuk berinisiatif, berekplorasi dan menciptakan sesuatu yang baru dan orisinal. Sangat miris melihat hal ini terjadi.

Setiap orang memiliki potensi kreatif, begitu juga halnya dengan anakanak pada umumnya anak senang bereksplorai dengan ide-ide cemerlangdan melihat dunia dengan cara yang alami dan asli. Anak mengekspresikan diri dengan cara mereka sendiri, mereka selalu mengadakan perubahan dan hal tersebut dilakukan oleh mereka sendiri.Khadija (2015: 163), mengungkapkan bahwa inti pengertian kreativitas anak yaitu kemampuan untuk menciptakan suatu produk yang baru. Orang tu dan orang-orang dewasa di sekitarnya hanya 
perlu mendorong dan memotivasi anak agar terus melakukan kreativitas, jika sejak kecil dewasa nanti ia akan memiliki kemampuan, keterampilan, dan profesi yang baik bahwan luar biasa.

Menurut Haryati (2012: 16), ada 8 cara untuk membantu anak dalam mengekspresikan kreativitas, yaitu: 1 . Membantu anak menerima perubahan (help children accept change), 2. Membantu anak menyadari bahwa beberapa masalah tidak mudah dipecahkan (help children realize that some problem have no easy answers), 3. Membantu anak untuk mengenai berbagai masalah memiliki solusi (help children recognize that many problem have a possible answers), 4. Memnatu anak untuk belajar menafsirkan dan menerima perasaannya (help children learn to judge and accept their own feeling), 5. Memberi penghargaan pada kreativitas anak (reward children for being creative), 6. Bantu anak untuk merasa nyaman dalam melakukan kreativitas dan dalam memecahkan masalah (help children feel joy in their creative productions and in working trough a problem), 7. Bantu anak untuk menghargai perbedaan dalam dirinya (help children appreciate themselves for being diffrerent), dan 8. Bantu anak dalam membangun ketekunan dalam dirinya (help children develop perseverance).

Musbikin dalam (Asrul dan Syukri, 2016: 12), kreativitas merupakan kemampuan memulai ide, melihat hubungan yang baru atau tak diduga sebelumnya, kemampuan memformulasikan konsep yang tak sekedar menghafal, menciptakan jawaban baru untuk memecahkan masalah yang ada dan mendapatkan pertanyaan baru yang perlu dijawab.

Kreativitas adalah suatu kemampuan untuk menciptakan ide yang kreatif atau gagasan baru, dalam Kreativitas dalam bidang seni diartikan sebagai karya yang memadukan gagasan seseorang yang terampil dan dilihat dari pengalaman atau pengetahuan yang sudah ada sebelumnya.Kemampuan ini untuk mewujudkan karya seni sebagai hasil ketrampilan kreativitas yang terorganisir dengan baik. Pengembangan kreativitas dilakukan dalam kegiatan bermain serta diarahkan untuk merangsang kemampuan anak agar anak dapat membuat kombinasi baru, sebagai kemampuan untuk memproduksi respon yang tidak biasa, serta merangsang agar anak berpikir Perkembangan kreativitas menekankan pada proses untuk memperoleh keterampilan yang dapat dilakukan anak, keterampilan seni di perlukan rangsangan untuk mengembangkan ide kreatif anak secara optimal.

d. Faktor-Faktor Yang Mempengaruhi Kreativitas

Safriyanti Dewi, (2018: 10) mengungkapkan bahwa faktor-faktor yang mempengaruhi kreaktivitas anak usia dini diantaranya yaitu faktor internal dan eksternal. Faktor internal adalah faktor yang berasala dari dalam diri anak seperti faktor biologis dan fisikologis.Sedangkan faktor eksternal adalah faktor yang berasal dari luar dirinya seperti faktor lingkungan keluarga, sekolah, dan masyarakat.

Berdasarkan pendapat diatas dapat diuraikan faktor-faktor yang dapat mempengaruhi kreaktivitas anak usia dini yaitu:

1) Faktor Internal

Merupakan faktor yang berasal dari dalam diri anak yang dapat mempengaruhi kreaktivitasnya yaitu:

a) Faktor biologis yaitu perkembangan kreaktivitas anak mempengaruhi oleh gen yang diwarisi oleh kedua orang tuanya. Selain menghasilkan kesamaan fisik, genetik juga dapat menghasilkan ciri-ciri psikologis seperti bakat dan kecerdasan. Bakat dan kecerdasan diyakini dapat mempengaruhi kreaktivitas anak. Biasanya anak yang berbakat dan 
memiliki kecerdasan tinggi akan menunjukkan kreaktivitas yang baik dibandingkan anak yang tidak berbakat dan memiliki kecerdasan rendah.

b) Faktor fisikologis. Kesehatan memiliki pengaruhi terhadap perkembangan kreaktivitas anak. Sehat dan aktifnya indera pada anakanak. Hal ini menunjukkan bahwa anak yang sehat akan menunjukkan kreaktivitas yang lebih baik dan sebaliknya jika anak mengalami kesehatan yang buruk dan kondisi tidak sehat disebabkan karena penyakit atau kecalakaan dapat menghambatnya perkembangan kreaktivitasnya.

2) Faktor Eksternal

Faktor eksternal merupakan faktor yang berasal dari lingkungan anak yang dapat mempengaruhi perkembangan kreaktivitasnya yaitu:

a) Lingkungan keluarga. Lingkungan keluarga merupakan lingkungan pertama dan utama yang mempunyai peran penting dalam mendidik anak. Pola asuh yang diterapkan orang tua sangat mempengaruhi terhadap tumbuh kembang anak. Pola asuh otoriter orang tua yang mengekang kebebasan anak untuk mengembangkan dirinya secara utuh seperti melarang anak bermain, serba membatasi, dan memaksa anak untuk menuruti perintah orang tua justru akan menjadikan anak kurang memiliki inisiatif dan tidak percaya diri sehingga dapat menghambat kreaktivitasnya. Sebaliknya, jika seorang anak dibiasakan dengan pola asuh yang demokratis dengan suasana keluarga yang terbuka, saling menghargai, mendengarkan pendapat, dan memberikan kesempatan yang luas kepada anak untuk melakukan kegiatan sesuia dengan minatnya maka anak tumbuh menjadi sosok yang kreatif, terbuka, penuh inisiatif dan percaya diri.

b) Lingkungan sekolah. Sekolah merupakan lingkungan pendidikan terpenting setelah di keluarga. Di sinilah pertama kalinya anak mengenal dunia luar dengan ruang lingkup yang lebih besar dari rumahnya. Lingkungan sekolah ini tentunya lebih beragam dan kompleks. Segala sesuatu dari lingkungan sekolah dapat mempengaruhi kreaktivitas anak, seperti guru dengan segala potensinya, banyaknya teman sebaya, system pembelajaran, serta sarana dan prasarana yang ada di sekolah.

c) Lingkungan masyarakat. Faktor budaya, kebiasaan, agama, dan keadaan demografi yang ada pada suatu masyarakat diakui atau tidak memiliki pengaruh dalam perkembangan kreativitas anak. Misalnya anak yang tinggal di kota perkembangan kreativitasnya akan berbeda dengan anak yang tinggal di desa.

e. Pentingnya Pengembangan Kreativitas Sejak Dini

Manusia lahir dengan membawa potensi kreatif. Dengan potensi kreativitas alami yang dimiliki, anak akan senantiasa membutuhkan aktivitas yang syarat dengan ide kreatif. Secara alami rasa ingin tahu dan keinginan untuk mempelajari sesuatu itu telah ada dan dikaruniakan oleh Tuhan. Maka secara natural anak pun memiliki keampuan untuk mempelajari sesuatu menurut caranya sendiri. Pada awal perkembangannya seorang bayi dapat memanipulasi gerakan ataupun suara hanya dengan kemampuan pengamatan dan pendengarannya. Ia belajar mencoba, meniru, berkreasi, dan mengekspresiakan diri sesuai dengan gayanya sendiri. Sangat penting untuk memperlihatkan keindahan pada anak dan membantu mereka mengembangkan penghargaan pada seni murni. Bagi sebagian anak, ekspresi 
seni merupakan cara paling alami untuk mengungkapkan fikiran, perasaan, dan pemikiran sambal menantang imajinasi mereka dan mengembangkan kemampuan merenung dan memecahkan masalah dengan kreatif, Syafarudin (2011: 85)

Jika kita membatasi anak untuk mempelajari sesuatu, maka kita akan menghambat mereka untuk mempelajari suatu hal yang besar. Atau malah mungkin mematikan keinginan mereka untuk belajar. Karena anak kreatif berbeda dengan anak yang pandai ataupun patuh dan baik, dan bukan bakat yang hanya terjadi karena faktor lingkungan. Namun kreativitas lebih banyak ditentukan oleh faktor lingkungan, terutama pola asu orang tuanya. Dengan demikian, orang tua memiliki peran yang sangat penting dalam proses pengembangan potensi kreativitas anak. Hal ini sejalan dengan yang diungkapkan oleh Safaruddin, yaitu: beberapa pola asuh kreatif dari orang tua sebenarnya dapat ditumbuhkan dari kehidupan keseharian anak. Misalnya membiasakan anak untuk bertanya tentang segala hal karena pertanyaan itu akan merangsang daya fikir anak. Begitu juga suasana rumah perlu seiring mungkin diubah untuk menghindari rutinitas. Ketika anak sedang tertarik dengan hal-hal baru menampakkan kegairan, maka perlu diberi kebebasan untuk mengembangkan berbagai daya fantasinya. Begitu juga ketika anak menanyakan sesuatu, seperti tentang ikan atau bunga, akan lebih kreatif apabila irang tua memberikan barang yang dimaksud atau mengajak anak melihat langsung benda tersebut. pengenalan langsung anak terhadap alam merupakan cara orang tua kreatif dalam memberikan media pendidikan yang seluas mungkin pada anak. Sebagai orang tua pada dasarnya akan merasakan bahwa kreativitas laksana ruh yang mampu membangkitkan seluruh anak,Syafarudin (2011: 88-89).

\section{Finger Painting}

\section{a. Pengertian Finger Painting}

Menurut Montolalu dalam Maria Evivani (2004: 27) pembelajaran melukis menggunakan jari atau finger painting memiliki tujuan yaitu mengekspresikan kesenangannya melalui media lukis dengan menggunakan bagian telapak tangan dan jari jemari tangan untuk melatih otot-otot tangan dan jari, koordinasi mata tangan, melati kecakapan mengkombinasikan warna, memupuk perasaan terhadap gerakan tangan. Finger painting adalah jenis kegiatan membuat gambar yang dilakukan dengan cara menggoreskan adonan warna (bubur warna) secara langsung dengan jari tangan secara bebas di bidang gambar, batasan jari disini adalah semua jari tangan, telapak tangan, samapai pergelangan tangan.

Finger painting ialah salah satu kegiatan yang melibatkan kemampuan motorik jari hingga pergelangan tangan anak, yang berarti dalam kegiatan ini secara tidak langsung melatih motorik halus pada bagian tangan yang melibatkan. Hal ini juga dapat memberikan kesenangan pada anak bersentuhan langsung pada objek (bahan dan alat) yang digunakan pada kegiatan ini.

Alat dan bahan untuk bermain anak sebaiknya menggunakan objek yang aman supaya tidak melukai bagian tubuh anak. Alat dan bahn yang digunakan dalam permainan finger painting ini dimudahkan untuk ditemukan dan aman bagi anak. Alat dan bahan yang digunakan untuk bermain finger painting yakni plastik untuk alas, kertas putih, cat dengan 4-8 warna, celemek serta tepung kanji Montalalu (2009: 28)

b. Tujuan Kegiatan Finger Painting 
Semua kegiatan memiliki tujuan dan manfaat. Tujuan yang paling utama yakni untuk memberikan kesenangan dan untuk mendapatkan pengetahuan baru dari permainan yang telah dimainkan. Tujuan finger painting yakni untuk meningkatkan kemampuan berpikir dan berbuat kreatif, mengembangkan kemampuan dalam mengungkapkan nilai-nilai estetika dengan menggambar karya-karya kreatif Kurniati, dkk (2010: 48).

Pendapat lain mengetahui tujuan finger painting menurut Montalalu (2009: 52) yaitu:

1) Mengembangkan fantasi, Imajinasi, dan kreasi

2) Mengembangkan ekspresi melalui media lukis dengan gerakan tangan

3) Melalui otot-otot tangan atau jari, koordinasi otot, dan mata

4) Melatih kecakapan dan mengkombinasikan warna

5) Memupuk perasaan terhadap gerakan tangan

6) Memupuk peraasaan keindahan

Pada saat kegiatan finger painting anak diberi kesempatan untuk menuangkan segala ide yang dimilikinya melalui setiap goresan lukis. Hal ini tentu saja akan bermanfaat untuk perkembangan anak. Anak diberi kebebasan meluapkan segala emosi serta yang paling penting yaitu anak dapat melakukan eksprimen tampa adanya unsur paksaan. Anak diberi kebebasan untuk memilih warna lalu mencampurkannya dengan warna yang lain sehingga dapat menghasilkan warna-warni yang baru. Proses inilah yang seharusnya terjadi pada kegiatan belajar anak. Anak mendapatkan ilmu atau pembelajaran baru melalui kegiatan yang anak lakukan sendiri buka hanya mendengarkan setiap perkataan yang diucapkan oleh guru.

Imajinasi anak dapat berkembang dengan menciptakan hasil karya kreatif berupa lukisan dari hasil jiplakan jari tangan yang tentu saja berbeda antara anak. Kreativitas anak akan berkembang dengan diberikan kebebasan dalam melakukan kegiatan karena anak bereksplorasi dengan mebuat karya kreatif dan dapat bereksprimen dengan melakukan paroses pencampuran warna. Kegiatan finger painting bukan hanya mengembangkan kreativitas anak akan tetapi dapat pula mengembangkan motorik halusnya Nadiyah Maulidah Rachmah (2018: 50).

c. Langkah-Langkah Melakukan Finger Painting

Langkah awal dalam melakukan kegiatan finger painting dalam membuat adonan cat finger paintingnya. Berikut ini disajikan beberapa cara untuk membuat pewarna finger painting, yaitu sebagai berikut:

1) Bahan

a) Cat air warna warni

b) Air

2) Alat

a) Wadah atau mangkuk

b) Kertas putih

c) Cangkir

3) Cara membuat:

a) Tuangkan cat air warna warni ke dalam wadah

b) Masukkan pewarna lalu tuangkan air secukupnya

c) Aduk hingga merata

d) Siapkan kertas gambar besar (ukuran kertas sesuai dengan situs).

e) Kemudian anak dapat menggambar dengan jarinya yang sudah dilumuri adonan finger painting tadi.

Setelah membuat adonan cat finger painting, langkah selanjutnya yaitu: 
1) Tuangkan cat kental ke dalam cangkir, lalu si anak mencelupkan jarijarinya ke dalam cat dan kemudian menggambar di atas kertas dengan jarijarinya.

2) Tuangkan cat kental ke dalam wadah atau mangkuk. Tunjukkan pada mereka bagaimana caranya menggunakan telapak tangan dan jarinya untuk membuat pola yang berbeda.

3) Tuangkan beberapa warna cat di atas wadah plastik.

4) Campurkan cat dengan air dengan cara mengaduk menggunakan ujung jari.

5) Setelah itu di arahkan mereka untuk membuat pola atau atau gambar pada kertas dengan menggunakan jari-jari tangan.

6) Kemudian keringkan hasil gambar anak agar tidak basah sehingga gambar atau pola yang di buat anak dapat terlihat dengan jelas. Lalu, si anak dapat menggunakan tangannya untuk membuat pola.

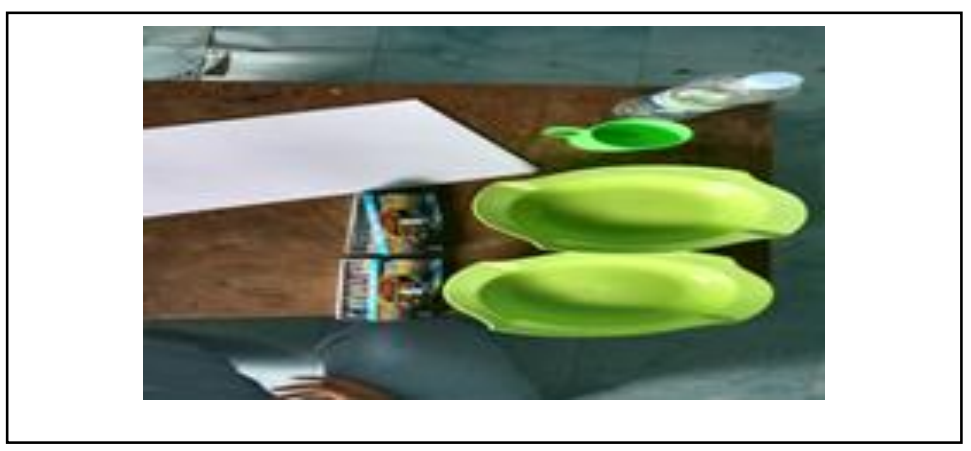

Gambar 1.Alat dan bahan

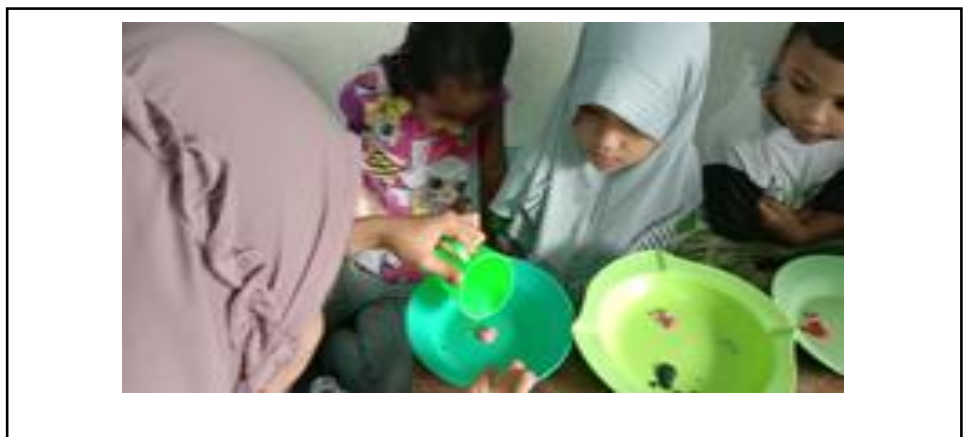

Gambar 2.Tuangkan air ke dalam wadah

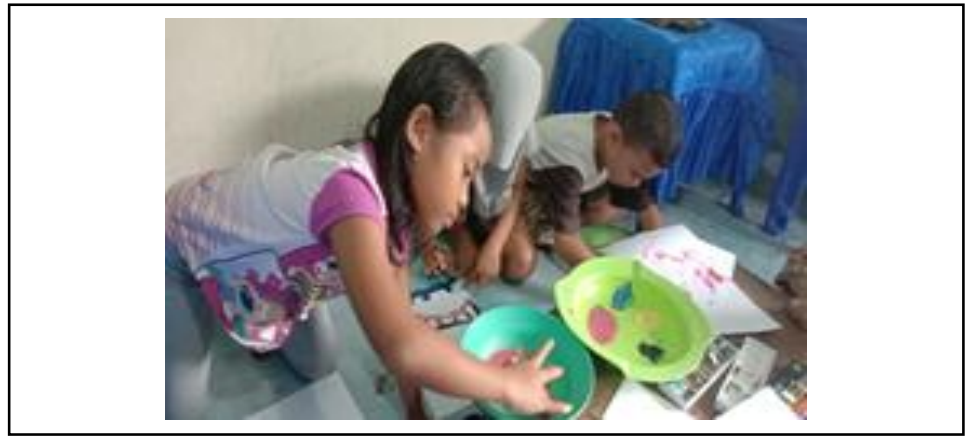

Gambar 3. Aduk cat air warna warni hingga merata 


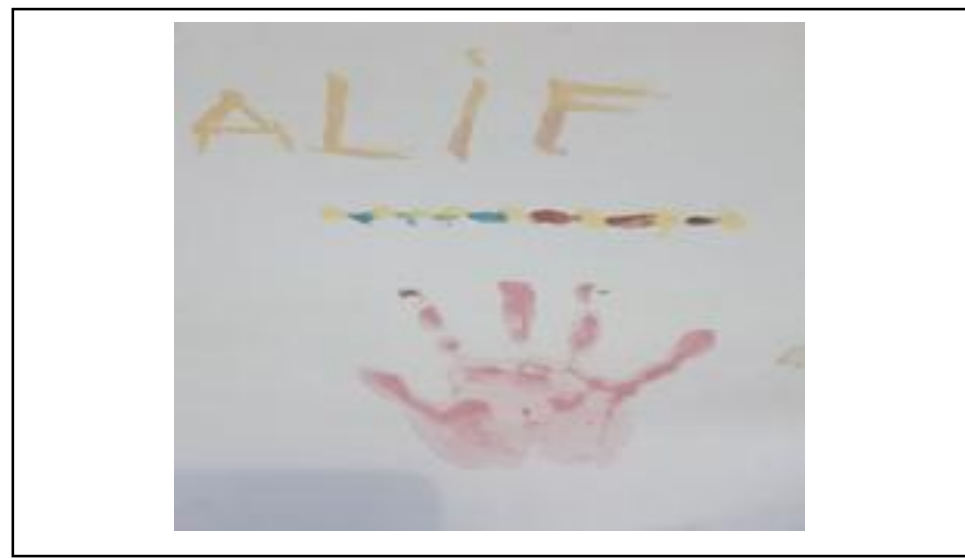

Gambar 4.Menggambar menggunakan lima jari

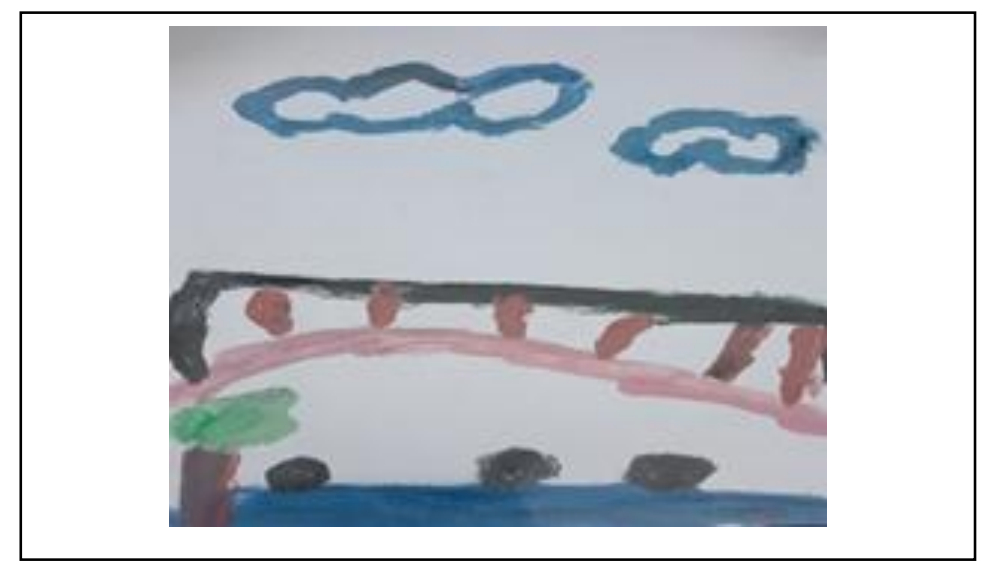

Gambar 5.Menggambar sebuah jembatan dengan menggunakn jari

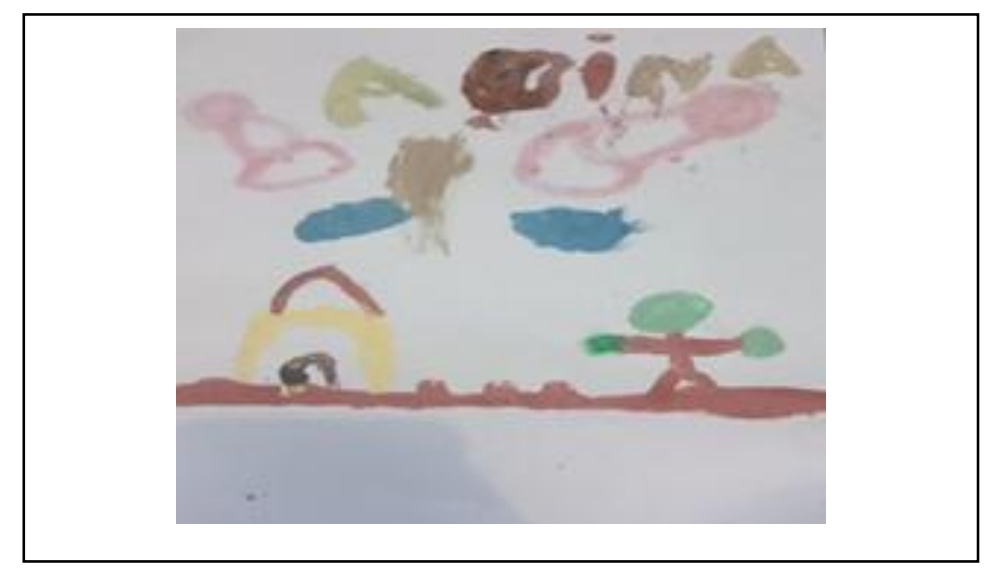

Gambar 6.Menggambar rumah dan pohon 


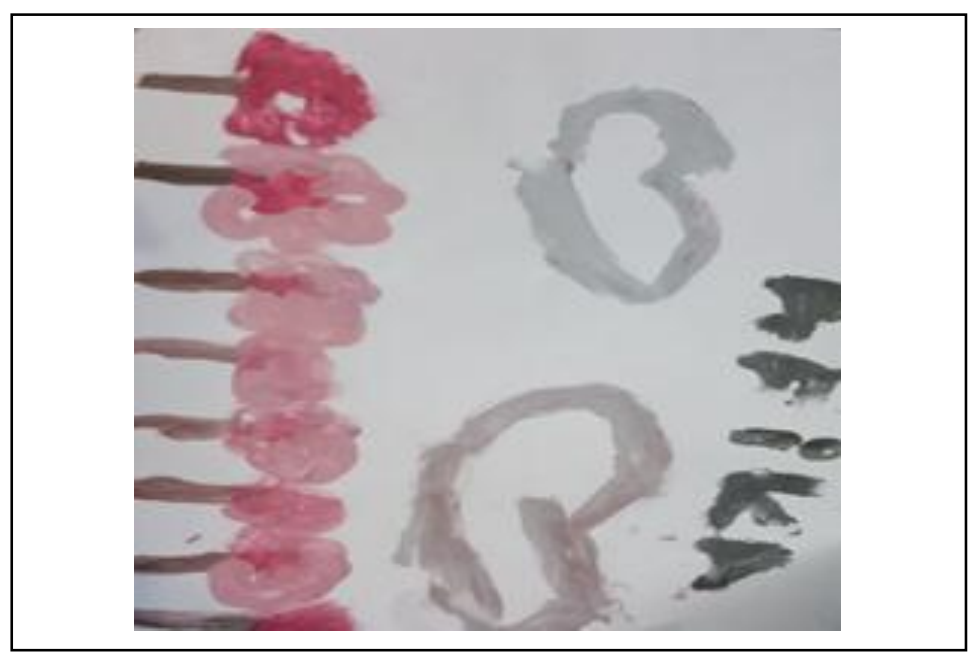

Gambar 7. Membuat pohon dan awan

Dengan menerapkan pembelajaran finger painting anak-anak dapat berekspresi secara bebas, dapat menuagkan imajinasi yang mereka miliki dalam bentuk gambar dan dapat meningkatkan krativitas yang mereka miliki.

Finger painting merupakan kegiatan menggambar yang melibatkan anak dalam meluapkan kreativitas dan imajinasi dengan menggunakan jari-jari mereka.Anak bebas berekspresi membuat pola atau gambar sesuai dengan imajinasi yang mereka inginkan. Selain itu finger painting secara tidak langsung dapat mengembangkan motorik halus anak karena pada kegiatan ini anak di berikan kebebasan dalam memilih warna dan membuat gambar yang tentu saja hasil gambar tiap-tiap anak berbeda.

Berikut ini beberapa penelitian yang terkait dengan kajian yang dilakukan adalah sebagai berikut:

a. Ari Sofia (2016) penelitian ini bertujuan untuk mengetahui pengaruh bermain finger painting terhadap kreativitas anak usia 5-6 tahun. Metode penelitian yang digunakan yaitu asosiatif kausal. Lokasi penelitian di RA Akhlakul Karumah Kotabumi. Dalam penelitian ini menggunakan pedoman observasi dan analisis data menggunakan analisis regresi. Berdasarkan hasil penelitian dapat disimpulkan bahwa adanya pengaruh antara bermain finger painting terhadap keativitas anak usia 5-6 Tahun.

b. Selia Dwi Kurnia (2015) penelitian ini untuk mengetahui pengaruh kegiatan painting dan keterampilan motorik halus terhadap kreativitas anak usia dini dalam seni lukis kelompok B taman kanak-kanak. Metode penelitian ini menggunakan penelitian ekprimen dengan desain treatment. Berdasarkan hasil penelitian dapat disimpulkan bahwa hasil kreativitas anak usia dini dalam seni lukis pada kelompok nak yang memeliki keterampilan motorik halus rendah yang diberi kegiatan finger painting lebih rendah dibandingkan kelompok anak yang diberi kegiatan brush painting

c. Suwarini (2014) penelitian ini bertujuan untuk mengembangkan krativitas anak melalui kegiatan finger painting pada kelompok B di TK Pertiwi Karangtengah Kecamatan Sragen, Kabupaten Sragen. Metode penelitian ini menggunakan penelitian tindakan kelas yang bertujuan untuk mengembangkan kreativitas anak melalui kegiatan finger painting. Adapun teknik pengumpulan data yang digunakan dalam penelitian ini adalah observasi, wawancara, dokumentasi dan catatan dilapangan. Teknik analisis data pada penelitian ini dilakukan secara diskriptif kualitatif dengan dua 
siklus, yaitu yang setiap siklusnya dilakukan dua kali pertemuan. Hasil penelitian ini menunjukkan adanya perkembangan kreativitas anak melalui kegiatan finger painting, yakni sebelum tindakan sampai dengan siklus II. Sebelum tindakan 38,3\%, siklus I 49,0\%, siklus II 79,0\%. Kesimpulan dari penelitian ini yaitu dengan kegiatan finger painting ini dapat mengembangkan kreativitas nak pada kelompok B di TK Pertiwi Karangtengah, Kecamatan Sragen, Kabupaten Sragen.

d. Febriyan Rachmawati (2016) tujuan dari penelitian ini dalah untuk mengetahui pengaruh bermain melukis terhadap kreativitas anak kelompok B TK Pertiwi Dukuh 1 Mojolaban Sukoharjo. Metode pada penelitian ini ialah metode kuantitatif menggunkan jenis penelitian eksprimen dengan design penelitian pre-eksprimental design. Teknik pengumpulan data dalm penelitian ini dilakukan melalui observasi partisipan dn dokumentasi. Hasil analisis data menggunakan $\mathrm{t}_{\text {test }}$ diperoleh nilai $\mathrm{t}_{\text {hitung }}-6,826 \leq \mathrm{t}_{\text {tabel }}$ yaitu -1.7709 maka $\mathrm{H}_{0}$ ditolak dan $\mathrm{H}_{\mathrm{a}}$ diterima yang berarti terdapat pengaruh bermain melukis terhadap kreativitas anak.

e. Lia Istiana (2016) penelitian ini bertujuan pada anak kelompok B di PAUD Melati Sawahan Panggul Trenggalek dilatarbelakangi oleh rendahnya perkembangan kreativitas anak terutama dalam hal bermain finger painting, disebabkan kurang adanya inovasi dalam pembelajaran yang diberikan oleh guru. Tujuan yang ingin dicapai dalam penelitian ini adalah untuk membuktikan apakah ada pengaruh bermain finger painting terhadap kreativitas anak usia dini. Penelitian ini mneggunakan pendekatan penelitian kuantitatif dengan desain penelitian pre eksprimental design dengan rancangan one-group pretest nd posttest design. Teknik pengumpulan data menggunakan statistik non parametrik uji jenjang bertanda wilcoxon (wilcoxon match pairs test) demgan rumus $t_{\text {hitung }}<\mathrm{t}_{\text {tabel }}$ jika $\mathrm{t}_{\text {tabel }}$ maka penelitian ini signifikan adanya du variabel. Hasil penelitian, data tentang kreativitas anak menunjukkan data pretest 110 dan posttest 168. Hasil analisis data uji wilcoxon diperoleh bahwa $t_{\text {hitung }}<t_{\text {tabel }}$ dengan taraf signifikan $5 \%$ yaitu $0<35$ maka $\mathrm{H}_{\mathrm{a}}$ diterima dan $\mathrm{H}_{\mathrm{o}}$ ditolak. Sehingga, hasil penelitian dapat disimpulkan bahwa bermain finger painting berpengaruh terhadap kreativitas anak kelompok B Di PAUD Melati.

Berdasarkan indikator/literatur yang dilakukan pada kegiatan finger painting adalah kegiatan seni rupa yang dilakukan dengan membuat adonan, dengan kriteria penilaian yaitu memegang sendok pengaduk adonan dan pewarna, mengambil adonan dan tidak tumpah, dan mengaduk adonan dan pewarna sampai berubah warna. Hal ini dapat membuat karya atau ide-ide baru, dengan kriteria yaitu mengambil adonan, mencelupkan jari tagan ke dalam adonan dan menempelkan jari ke atas kertas masing-masing, serta bentuk kombinasi gambar yang dihasilkan dengan teknik mengecap membuat suatu produk yang baru dan menarik sesuai dengan imajinasi anak.

\section{Simpulan}

Berdasarkan hasil penelitian dan pembahasan diatas bahwa dengan kegiatan finger painting dapat mengembangkan kreativitas anak kelompok B Penggunaan kegiatan finger painting untuk pembelajaran, ternyata sangat berpengaruh terhadap keterampilan motorik halus anak usia 4-5 tahun, pada kelompok B. Finger painting merupakan salah satu alternatif yang dapat melatih keterampilan motorik halus anak. Kegiatan finger painting juga digunakan oleh para pendidik anak usia dini sebagai salah satu kegiatan pembelajaran. Hal tersebut, karena kegiatan finger painting berpengaruh terhadap keterampilan motorik halus.Pada mulanya anak enggan untuk mencoba memainkan jari tangannya untuk kegiatan finger painting. Namun setelah anak mencobanya sendiri, anak merasa tertarik setelah dicontohkan oleh peneliti. 
Kegiatan finger painting melatih motorik halus anak, ternyata ini menjadi pengalaman tersendiri bagi anak-anak.Finger painting ini diharapkan dapat melatih keterampilan motorik halus anak dan dapat menumbuhkan serta mengembangkan potensi anak secara optimal.

Tujuan yang paling utama yakni untuk memberikan kesenangan dan untuk mendapatkan pengetahuan baru dari permainan yang telah dimainkan. Tujuan finger painting yakni untuk meningkatkan kemampuan berpikir dan berbuat kreatif, mengembangkan kemampuan dalam mengungkapkan nilai-nilai estetika dengan menggambar karya-karya kreatif

Kegiatan finger painting bermacam-macam jenisnya, seperti: membuat gambar macam-macam hewan, jenis tumbuhan, berbagai bentuk geometri, kendaraan, pemandangan, bangunan sekolah, masjid dan lain-lain. Dengan memberikan kegiatan finger painting kepada anak, dapat melatih keterampilan motorik halus anak agar lebih terampil.Guru juga sebaiknya dapat memberikan kondisi pembelajaran yang nyaman dan menyenangkan bagi anak. Agar anak tidak merasa bosan dalam pembelajaran dan anak dapat mengeksplorasikan daya imajinasinya kedalam kegiatan finger painting

\section{DAFTAR PUSTAKA}

Amin, 2007. Menyiapkan Masa Depan Anak Secara Islami. Jakarta: Azmah

Ari Sofia 2016. Pengaruh Bermain Finger Painting Terhadap Kreativitas Anak Usia 5-6 Tahun di RA Akhlakul Karumah Kotabumi.

Depdiknas, 2003.Undang-Undang Pendidikan Nasional No. 20 Tentang Sistem Pendidikan Nasional. Jakarta: Depdiknas

Febriyan Rachmawati 2016. Pengaruh Bermain Melukis Terhadap Kreativitas Anak Kelompok B Di TK Pertiwi Dukuh Mojolaban Sukoharjo

MusbikinDalam Asrul dan Ahmad Syukri, 2016. Strategi Pendidikan Anak Usia Dini. Medan: Perdana Publishing

Guiford Mohammad Ali dan Mohammad Asroni, 2004. Psikologi Remaja Perkembangan Peserta Didik. Jakarta: Bumi Aksara

Haryati, 2012. Aktivitas Cerdas Pengisi Kegiatan PAUD. Jakarta: Tugu Publisher

Kenedi, 2017. Pengembangan Kreativitas Siswa Dalam Proses Pembelajaran. Journal Ilmu Pendidikan Sosial, Sains, dan Humaniora Vol. 4 (Diakses 5 Juli 2020)

Kurniati, dkk, 2010.Strategi pengembangan kreativitas pada anak. Jakarta: Kecana Prenada Media Group

Khadija, 2015. Media Pembelajaran Anak Usia Dini. Medan: Perdana Publishing

Kim, M., Roh \& Cho. 2016. Creativity of Gifted Student in an Integrated Math-Science Instruction. Journal of Skill and Creativity Vol.19 pp38-48 (Diakses 3 Juli 2020)

Lia Istiana 2016. Pengaruh Bermain Finger Painting Terhadap Kreativitas Anak Usia Dini Kelompok B Di PAUD Melati 
Montolalu dalam Maria Evivani, 2004. Permainan finger painting Untuk Pengembangan Kemampuan Motorik Halus Anak Usia Dini. Jurnal Pendidikan dan Pembelajaran Anak Usia Dini Maret 2020.Vol 05 No 01 (Diakses 29 Juni 2020)

Montalalu, 2009. Bermain dan Permainan. Jakarta: Universitas Terbuka

Nadiyah Maulidah Rachmah, 2018. Efektivitas Kegiatan Finger Painting Terhadap Kreativitas Melukis Anak Kelompok B Raudlatul Athfal Muslimat NU 75 Miftahul Huda Gresik. Skripsi Pendidikan Islam Anak Usia Dini (Diakses 2 Juli 2020)

Pamadhi dan Sukardi, 2010. Seni Keterampilan Anak. Jakarta: Universitas Terbuka

Rahmawati, 2011. Strategi Pengembangan Kreativitas Pada Anak. Jakarta: Kencana

Rohani, 2017. Meningkatkan Kreativitas Anak Usia Dini Melalui Media Bahan Bekas. Journal Pendidikan Guru Raudhatul Athfal (Diakses 1 Juli 2020)

Rachmawati 2014. Strategi Pengembangan. Jakarta: Kencana Prenada Media Group

Sari 2016. Meningkatkan Keterampilan Motorik Halus Melalui Kegiatan Finger Painting di TK Goemerlang. Journal (Diakses 29 Juni 2020)

Safriyanti Dewi, 2018. Kreativitas Anak Usia Dini Di Ra Nur Hidayah. Kabupaten Labuhan Batu. Skripsi Pendidikan Islam Anak Usia Dini (Diakses 4 Juli 2020)

Santrock, 2011. Psikologi Pendidikan, Edisi Kedua. Jakarta: Kencana

Selia Dwi Kurnia 2015. Pengaruh Kegiatan Finger Paintingdan Keterampilan Motorik Halus Terhadap Kreativitas Anak Usia Dini Dalam Seni Lukis Pada Kelompok B Di Taman Kanak-Kanak Pertiwi Matanna Tikka Kecamatan Tanete Riattang, Kabupaten Bone

Syafarudin, 2011. Pendidikan Prasekolah. Jakarta: Perdana Publishing

Suratno, 1999. Pengembangan Kreativitas Anak Usia Dini. Jakarta: Departemen Pendidikan Nasional. Skripsi Jakarta (Diakses 27 Juni 2020

Suwarini 2014. Mengembangkan Kreativitas Anak Melalui Kegiatan Finger Painting Pada Kelompok B Di Pertiwi Karangtengah, Kecamatan Sragen, Kabupaten Sragen

Utami Munandar, 2009. Pengemangan Kreativitas Anak Berbakat. Jakarta: Rineka Cipta 